\title{
EFFECT OF DIETARY CHILLI POWDER ON GROWTH PERFORMANCE AND SERUM CHOLESTEROL CONTENTS OF BROILER CHICKEN
}

\author{
NSBM Atapattu ${ }^{*}$ and UD Belpagodagamage \\ Department of Animal Science, Faculty of Agriculture, University of Ruhuna, Mapalana, Kamburupitiya, Sri \\ Lanka
}

Accepted : $21^{\text {st }}$ September 2010

\begin{abstract}
With the ban on the use of antibiotic growth promotants (AGP) in animal industry, search for alternatives to AGP has received a renewed scientific attention. Herbal extracts such as capsaicin have found to improve the growth performance of broiler chicken. Chilli (Capsicum annum) is a good source of natural capsaicin. Objective of this study was to determine the effects of dietary chilli powder (CHPW) on growth performance and serum cholesterol levels of broiler chicken. One hundred broiler chicks in 20 cages received one of the four experimental diets containing either 0 (control), 1,3 or $5 \%$ of CHPW from day 30-49. Serum cholesterol contents were determined on day 47. Mortality rates, feed and water intake were not affected by the dietary CHPW. The birds fed $5 \%$ CHPW gave higher $(p<0.05)$ live weight on day 49 and weight gain from day 30-49, compared to control group. Though not significant, feed conversion ratio (FCR) of the bids fed 5\% CHPW (2.14) was $6 \%$ better than that of the control birds (2.28). Visceral organ weights, abdominal fat pad percentage and the litter parameters were also not affected by the dietary CHPW. Serum cholesterol levels of the birds fed $1 \%$ CHPW were significantly lower than those of the birds fed either 0 or 5\% dietary CHPW. Results of this experiment conclude that 5\% dietary CHPW had growth promotant effect while 1\% CHPW had hypocholesterolaemic effect in broiler chicken.
\end{abstract}

Key words: Chilli, capsaicin, growth promotants, broiler, cholesterol

\section{INTRODUCTION}

The use of antibiotic growth promotants to improve animal performance has been practiced during last 50 years. However, when animals are exposed to low levels of antibiotics, resistant cells survive and grow producing antibiotic-resistant populations. Consequently, the use of AGP in food animals has been banned in the European Union (European Union 1998) and many other countries. In this context, alternatives to AGP are of importance. Most supplements which use as alternatives to AGP have effects on gut microflora, either directly or indirectly (Garcia et al. 2007). Herbs, spices, and various plant extracts have received increased attention as possible alternatives to AGP, since they are considered as natural products (Harnandez et al. 2004). Griggs and Jacob (2005) reviewed the antimicrobial and growth promotant effects of a range of plant extracts which have been studied in poultry. Herbs having potentials to be used as alternatives to AGP include thyme (Thymus vulgaris), clove (Syzygium aromaticum), turmeric (Curcuma longa), black pepper (piper nigram), oregano (Oregano vulgar) and garlic (Alum sativa). Active ingredients of the extracts of above herbs include thymol, eugenol, curcumin, piperin, carvacrol, cynnamaldehyde and capsaicin.

\footnotetext{
*Corresponding author:nsbm@ansci.ruh.ac.lk
}

Capsaicin, a homovanillic acid derivative (8-methyl -N-vanillyl-6-moneamide) is an irritant and vasoactive compound from chilli (Capsicum annum) powder (Vicente et al. 2007). Several studies (Garcia et al. 2007; Hernadez et al. 2004) and Kamel et al. 2001) have shown that plant extracts containing a mixture of capsaicin, cinnamaldehyde and carvacrol improved the growth performance of broiler chicken. Dried pods of Capsicum annum or chilli contain $1.8 \%$ capsaicin (Pruthi 2003) and thus are good sources of natural capsaicin. No study has evaluated the growth promotant effects of capsaicin alone in poultry. The objective of this study wan to evaluate the effects of dietary chilli powder supplementation on growth performance, visceral organ weights and serum cholesterol levels of broiler chicken.

\section{MATERIALS AND METHODS}

Day old broiler chicks were obtained from a local hatchery and reared under normal management conditions until day 28. Until being used for the experiment, chicks were fed commercial broiler starter (until day 21) and finisher (from day 22-29) diets. On day 29, chicks were weighed and 100 birds were allocated into twenty cages so that between cage weight variation was minimum. Cages were randomly allocated into four dietary treatments. Chilli powder was purchased from a local 
grinding mill and analyzed for crude protein. Four broiler finisher diets containing graded levels $(0,1$, 3 and 5\%) of CHPW were prepared (Table 1). All diets met or exceeded the nutrient levels as set by NRC (1994).

Except the CP content, levels of other nutrients such as minerals and, energy of CHPW were not considered in the ration formulation. From day 3049 chicks were given experimental diets and water ad libitum. Daily feed and water intakes and weekly live weights were recorded. Feed samples were analyzed for $\mathrm{pH}$ and crude protein. A sample of feed was mixed with distilled water $(1: 1 ; \mathrm{w} / \mathrm{w})$ and allowed to settle for 30 minutes and used for the $\mathrm{pH}$ determination. Faecal and litter samples were also analyzed for $\mathrm{CP}$, dry mater and $\mathrm{pH}$.

Table 1: Ingredient and nutrient composition and $\mathrm{pH}$ of the experimental diets

\begin{tabular}{|c|c|c|c|c|}
\hline \multirow{2}{*}{$\begin{array}{l}\text { Ingredients } \\
(\%)\end{array}$} & \multicolumn{4}{|c|}{ Dietary chilli powder level (\%) } \\
\hline & 0 & 1 & 3 & 5 \\
\hline Fish meal & 3.5 & 5.5 & 4.5 & 5 \\
\hline Rice bran & 21 & 19.5 & 20 & 20 \\
\hline Maize meal & 34.5 & 37.5 & 33 & 33 \\
\hline Coconut oil meal & 10 & 9.5 & 10 & 9 \\
\hline Coconut oil & 7 & 7 & 7 & 7 \\
\hline Soyabean meal & 15 & 10 & 13 & 14 \\
\hline Gingerly oil meal & 17 & 8 & 8 & 5 \\
\hline Bone meal & 1 & 1 & 0.8 & 0.8 \\
\hline L- Lysine & 0.09 & 0.1 & 0.09 & 0.09 \\
\hline Shell powder & 0.9 & 0.9 & 0.7 & 0.9 \\
\hline $\begin{array}{l}\text { Dicalcium phos- } \\
\text { phate }\end{array}$ & 0.042 & 0.042 & 0.03 & 0.042 \\
\hline Salt & 0.25 & 0.25 & 0.25 & 0.25 \\
\hline DL- Methionine & 0.04 & 0.04 & 0.04 & 0.04 \\
\hline $\begin{array}{l}\text { Chilli powder } \\
\text { Nutrient compo- } \\
\text { sition }\end{array}$ & 0 & 1 & 3 & 5 \\
\hline$* \mathrm{CP}(\mathrm{g} / \mathrm{kg})$ & 188 & 191 & 190 & 189 \\
\hline $\mathrm{CF}(\mathrm{g} / \mathrm{kg})$ & & & & \\
\hline ME (Kcal/kg) & & & & \\
\hline $\mathrm{Ca}(\mathrm{g} / \mathrm{kg})$ & & & & \\
\hline $\begin{array}{l}\text { Non phytate } \\
\text { phosphorus (g/ } \\
\text { kg) }\end{array}$ & & & & \\
\hline Lysine (g/Kg) & & & & \\
\hline $\begin{array}{l}\text { Met.+ Cys( (g/ } \\
\text { kg) }\end{array}$ & & & & \\
\hline $\mathrm{pH}$ & $6.74^{\mathrm{a}}$ & $6.54^{\mathrm{b}}$ & $6.51^{\mathrm{b}}$ & $\begin{array}{l}6.54^{\mathrm{b}} \\
0.03^{1} \\
0.00^{2}\end{array}$ \\
\hline
\end{tabular}

* Analyzed, 1. SEM, 2. Probability
On day 47, blood samples were collected from one randomly selected bird from each cage. Serum cholesterol contents were determined using commercial cholesterol determination kit (SPINREACT, Ctra, Santa, Coloma, Spain).

On day 49, six randomly selected birds from each treatment were killed and dissected. Weights of the internal organs such as liver, heart, gizzard, pancrease, proventriculus, empty carcass, and the abdominal fat pad were determined. Data were analyzed using the GLM procedure of SAS (1989). Effects were considered significant when $\mathrm{P}<0.05$. Means were separated by using Duncan Multiple range test.

\section{RESULTS AND DISCUSSION}

Inclusion of CHPW significantly reduced $(p<0.05)$ the $\mathrm{pH}$ of feeds compared to the control diet (Table 1). Proximate analysis showed that the $\mathrm{CP}$ content of CHPW was as high as $12 \%$. Famurewa et al. (2006) and USDA National Nutritional Data Base (http://www.nal.usda.gov/fnic/foodcomp/cgi-bin/ list nut edit.pl) have also reported similar CP value for Capsicum annum. The $\mathrm{CP}$ content of CHPW was higher than cereals such as maize, wheat, sorghum and their by products such as brans as given by NRC (1994). However, the actual protein value of CHPW depends on the level of true proteins, amino acids and their digestibility values. In this experiment, rations were formulated on the basis that CHPW contains $12 \% \mathrm{CP}$. The analyzed $\mathrm{CP}$ contents of the experimental diets were more or less similar (Table 1). Had the quality of $\mathrm{CP}$ in CHPW been inferior, either due to low true protein content or low digestibility of them, birds fed diets with CHPW, at least those fed 5\% CHPW, should have showed poor performance. However, birds fed $5 \%$ CHPW showed significantly higher live weight on day 49 and weight gain from day 30-49. This observation leads to two assumptions. Firstly, the proteins in CHPW may not be inferior in quality. Several studies (Hernandez et al. 2004; Garcia et al. 2007) have shown that plant extracts such as capsaicin improved the digestibility values of diets in broilers. Secondly, it may be argued, though the quality of CP in CHPW diets were inferior, the improved digestion arising from capsaicin compensated the adverse effects associated with poor protein quality of the diets supplemented with CHPW.

The hypothesis that CHPW improved the digestion and thereby the growth performance of broilers is further supported by the growth performance data as shown in Table 2. CHPW contains as high as 3240 Kcal of gross energy/kg (http:// www.nal.usda.gov/fnic/foodcomp/cgi-bin/ list_nut_edit.pl). As the birds fed diets with CHPW 
received an additional amount of energy, feed intake should have been lower for those birds. But that was not the case in this experiment. Even though the total feed intake (from day 30-49) was not significantly different between treatments, during 30-37 day, feed intake of the birds fed 5\% CHPW (130 g/day) was tend to be higher $(\mathrm{p}=0.08)$ than that of the birds fed $0 \%$ CHPW (120 g/day). The effect became significant $(\mathrm{P}<0.05)$ between 38 44 day. The reason/s for this observation is/are not clear.

Mortality percentages of the birds fed $0,1,3$ and $5 \% \mathrm{CHPW}$ were $3.3,3.4,0$ and $0 \%$, respectively and were not significantly different between treatments. Interestingly, live weight of the birds fed 5\% CHPW on day 37, 44 and 49 were significantly higher than the respective values of the birds fed other diets. Further, the live weight gain of the birds fed 5\% CHPW was also significantly higher than that of the birds fed either $0 \%$ or $1 \%$ CHPW. Even though not significant, increasing levels of dietary CHPW improved the FCR. For example, FCR of the birds fed $0 \%$ CHPW (2.28) improved by about

Table 2: Effects of dietary chilli powder on growth performance of broiler chicken

\begin{tabular}{|c|c|c|c|c|c|c|}
\hline \multicolumn{7}{|c|}{ Dietary chilies powder level (\%) } \\
\hline & 0 & 1 & 3 & 5 & SEM & $\mathrm{P}$ \\
\hline \multicolumn{7}{|c|}{ Feed intake $(\mathrm{g} / \mathrm{b} / \mathrm{d})$} \\
\hline Day $30-37$ & 120. & 116 & 123 & 130 & 1.6 & 0.08 \\
\hline Day $38-44$ & $120^{\text {ba }}$ & $116^{\mathrm{b}}$ & $127^{\mathrm{a}}$ & $127^{\mathrm{a}}$ & 2.4 & 0.04 \\
\hline Day $45-49$ & 139 & 138 & 143 & 145 & 2.5 & 0.33 \\
\hline Day 30-49 & 127 & 126 & 130 & 133 & 1.7 & 0.63 \\
\hline \multicolumn{7}{|c|}{ Water intake $(\mathrm{ml} / \mathrm{b} / \mathrm{d})$} \\
\hline Day $30-37$ & 369 & 310 & 210 & 345 & 25 & 0.10 \\
\hline Day $37-44$ & 411 & 344 & 391 & 406 & 14 & 0.33 \\
\hline Day $45-49$ & 399 & 371 & 402 & 394 & 9. & 0.64 \\
\hline Day 30-49 & 397 & 343 & 377 & 380 & 8 & 0.16 \\
\hline \multicolumn{7}{|c|}{ Water feed ratio } \\
\hline Day 30-49 & 3.14 & 2.74 & 2.88 & 2.86 & 0.07 & 0.27 \\
\hline \multicolumn{7}{|c|}{ Live weight (g) } \\
\hline Day 30 & 1373 & 1366 & 1369 & 1408 & 11 & 0.59 \\
\hline Day 37 & $1766^{\mathrm{b}}$ & $1738^{\mathrm{b}}$ & ${ }^{b} 1770^{b}$ & $1866^{\mathrm{a}}$ & 17 & 0.04 \\
\hline Day 44 & $2148^{b}$ & $2083^{\mathrm{b}}$ & ${ }^{b} 2153^{b}$ & $2261^{a}$ & 22 & 0.02 \\
\hline Day 49 & $2446^{\mathrm{b}}$ & $2375^{\mathrm{b}}$ & $2455^{\mathrm{b}}$ & $2579^{\mathrm{a}}$ & 23 & 0.00 \\
\hline \multicolumn{7}{|c|}{ Weight gain $(\mathrm{g} / \mathrm{b})$} \\
\hline Day 30- 49 & $1072^{b}$ & $1008^{\mathrm{b}}$ & b $1085^{\text {ba }}$ & $1172^{a}$ & 19 & 0.01 \\
\hline \multicolumn{7}{|c|}{ Feed conversion ratio } \\
\hline Day 30-37 & $2.18+$ & 2.20 & 2.16 & 1.98 & 0.05 & 0.45 \\
\hline Day 38-44 & 2.28 & 2.40 & 2.36 & 2.28 & 0.05 & 0.72 \\
\hline Day 45-49 & 2.34 & 2.38 & 2.38 & 2.30 & 0.02 & 0.79 \\
\hline Day 30-49 & 2.28 & 2.40 & 2.28 & 2.14 & 0.04 & 0.18 \\
\hline
\end{tabular}

Values within a row with different superscripts are significantly $(\mathrm{p}<0.05)$ different
$6 \%$ to 2.14 when dietary CHPW level was $5 \%$. Several studies (Bravo 2008; Hernandez et al. 2004 and Garcia et al. 2007) have reported that mixtures of plant extracts containing carvacrol, cynnamaldehyde and capsaicin improved the performance of broiler chicken. Hermandez et al. (2004) found that capsaicin increased the enzyme secretion in the digestive tract, thereby enhanced digestion and increased the nutrient availability. Improved growth performance of the broilers fed 5\% CHPW suggests that capsaicin alone also enhances the performance of broilers.

Assuming that capsicum contains $1.8 \%$ capsaicin (Pruthi 2003) it was calculated that the capsaicin contents of diets containing 1, 3 and 5\% CHPW were 180, 540 and 900ppm. Commercial plant extracts containing capsaicin has found to be effective at relatively lower concentrations. For examples, Hernandez et al. (2004) found that 200ppm of Xtract (Axiss, Archamps, France) containing oregano, cinnamon and pepper improved growth performance in broilers. Though CHPW is normally used as spices in human foods, it's a nutrient rich feed ingredient. Chilli contains $10.5 \% \mathrm{CP}, 5.8 \%$ lipids, $1.6 \%$ total phosphorus, $1.9 \%$ potassium, $0.47 \%$ lysine, $0.12 \%$ methionine and $3240 \mathrm{Kcal}$ of gross energy $/ \mathrm{kg}$ (http://www.nal.usda.gov/fnic/ foodcomp/cgi-bin/list nut edit.pl). Therefore, apart from growth promoting effects, dietary CHPW could be regarded as a source of other nutrients too. Dietary CHPW had no significant effects on internal organ weights (Table 3) and litter parameters (Table 4). Hernandez et al. (2004) also found that plant extracts such as oregano, cinnamon, pepper and Labiatae (Labiatea extract, Furfural Espanol, Murcia, Spain) had no effects on internal organ weights of broilers. Interestingly, serum cholesterol contents of the birds fed $1 \%$ CHPW was significantly lower than that of the birds fed $0 \%$ or $5 \%$ CHPW fed birds. Several other studies have also shown that capsaicin has hypocholesterolaemic ef-

Table 3: Effects of dietary chilli powder on the cacass parameters $(\%$ of empty carcass weight) and serum cholesterol contents of broiler chickens

Dietary chilies powder level (\%)

\begin{tabular}{lcccccc} 
Parameters & 0 & 1 & 3 & 5 & SME & P \\
\hline Live weight & 2708 & 2700 & 2632 & 2760 & 47 & 0.84 \\
De- skein weight & 2314. & 2316 & 2226 & 2372. & 38 & 0.65 \\
Carcass weight & 1767 & 1751 & 1757 & 1816 & 30 & 0.89 \\
Liver weight & 2.95 & 3.08 & 2.77 & 2.48 & 0.09 & 0.09 \\
Gizzard weight & 1.48 & 1.67 & 1.48 & 1.49 & 0.05 & 0.55 \\
Pancreas & 0.22 & 0.17 & 0.18 & 0.18 & 0.00 & 0.12 \\
Proventiculm & 0.41 & 0.39 & 0.36 & 0.42 & 0.01 & 0.21 \\
Total fat & 2.98 & 3.08 & 2.68 & 3.24 & 0.14 & 0.58 \\
Serum cholesterol $(\mathrm{mg} / \mathrm{dl})$ & & & & & \\
Day 47 & $151.38^{\mathrm{a}} 107.00^{\mathrm{b}} 134.33^{\mathrm{ba}} 151.33^{\mathrm{a}} 6.60$ & 0.02 \\
\hline
\end{tabular}


fects. For example, capsaicin, when fed along with cholesterol containing diets to female albino rats, significantly prevented the rise in liver cholesterol

Table 4: Faecal and litter properties of the broilers fed four levels of dietary chilli powder

\begin{tabular}{lllllll}
\hline \multicolumn{7}{c}{ Levels of dietary chilli powder (\%) } \\
\hline Parameters & 0 & 1 & 3 & 5 & SME & P \\
\hline Litter pH & 9.48 & 9.47 & 9.54 & 9.46 & 0.04 & 0.93 \\
Litter EC & 8.13 & 8.07 & 7.33 & 8.07 & 0.26 & 0.70 \\
Litter moisture & 58.51 & 58.86 & 63.48 & 63.38 & 0.86 & 0.13 \\
Feacal moisture & 79.80 & 76.92 & 70.16 & 67.67 & 3.67 & 0.65 \\
Feacal EC & 6.47 & 7.46 & 8.02 & 6.53 & 0.25 & 0.06 \\
Feacal pH & 7.31 & 7.07 & 7.06 & 7.05 & 0.05 & 0.29 \\
\hline
\end{tabular}

levels (http://www.sirisimpex.com/capsicum.htm). Bravo (2008) reported that broiler chicken fed plant extract (Xract 6930) containing 2\% capsaicin produced breast meat with higher protein and lower cholesterol. In this experiment, the levels of dietary CHPW that had growth promotant and hypocholesterolaemic effects were different; 5 and $1 \%$, respectively. Reason/s for this observation is/are not clear. None of the faecal and litter properties tested were significantly different between treatments (Table 4).

It is concluded that $5 \%$ dietary CHPW had growth promotant effect and 1\% CHPW had hypocholeaterolaemic effects in broiler chicken.

\section{REFERENCES}

Bravo D 2008 Plant extracts benefit producers and consumers. World Poultry. 6:16-17.

European Union 1998 Agriculture Council. 14 ${ }^{\text {th }}$ Dec 1998. Press Release No. 14127, Brussels.

Famurewa JAV, Oluwamukomi MO and Adenuga
AL 2006 Dehydration of Osmosised Red Bell Pepper (Capsicum annum). Journal of Food Technology 4 (4): 249-252,

Garcia V, Cotala-Gregori P, Hernandez F, Megias M.D and Madrid J 2007 Effect of formic acid and plant extracts on growth, nutrient digestibility, intestine mucosa morphology and meat yield of broilers. Journal of Applied Poultry Research. 16:558-563.

Griggs JP and Jacob JP 2005 Alternatives to antibiotics for organic poultry production. Journal of Applied Poultry Research. 14:750-756.

Henandez F, Mardrid J, Garcia V, Orengo J and Megias, MD 2004 Influence of two plant extracts on broiler performance, digestibility, and digestive organ size. Poultry Science. 83:169174.

Kamel C 2001 Tracing modes of action and the role of plant extracts in non-ruminants. Pages 135150 in Recent Advances in Animal Nutrition PC Garnsworty and J Wiseman ed. Nottingham University Press. Nottingham, UK.

National Research Council 1994 Nutrient requirements of Poultry. National Academy of Sciences, Washington, DC.

Pruthi JS 2003 Chemistry and quality control of capsicum and capsicum products.. In Capsicum and the genus Capsicum. Amit Krishna De. (eds). CRC Press, Taylor and Francois, UK. Pp 25-71

SAS Institute 1989 SAS Inst Inc. Cary, NC.

Vicente JL, Lopez C, Avila E, Hargis BM and Tellez G 2007 Effects of dietary natural capsaicin on experimental salmonella enteritis infection and yolk pigmentation in laying hens. International Journal of Poultry Science. 6(6):393 $-396$. 